\title{
UNEMPLOYMENT INSURANCE IN INTERWAR BELGIUM
}

\begin{abstract}
SUMmARY: In 1900, a special type of unemployment insurance was set up in Belgium: the so-called "Ghent system", which had some influence on the development of unemployment insurance in many European countries. This particular system was characterized by the important role played by the trade-union unemployment societies. The public authorities (in Belgium, from 1920 onwards, the central government next to the towns and provinces) encouraged the affiliation of the labourers to these societies by granting different sorts of financial support to the unemployed society members and to the societies themselves. During the crisis of the 1930s, this led to an important growth of Belgian trade-union membership. On the other hand, the quantitative growth of the labour movement due to this particular organization of unemployment insurance, led to many negative sideeffects for the trade unions (administrative chaos, financial problems, loss of combativity). Moreover, the employers' organizations strongly opposed this system of unemployment insurance, because they thought it reinforced the labour movement's power in society (strengthening of union membership, influence on wage formation, obstruction of deflation policy). This article examines the heated debates waged in the labour movement itself and between this actor, the employers' organizations and the government, to solve the many important problems posed by this type of social insurance. The Belgian pre-Second World War debate concerning unemployment insurance was of great importance for the shaping of the Welfare State in Belgium, which took its present-day form in 1944.
\end{abstract}

One could hardly claim that unemployment between the two world wars has been a neglected theme in contemporary historiography. The literature on this issue is growing steadily and is also dealing with increasingly diverse aspects. Yet it is undeniable that the majority of the studies on interwar unemployment concern themselves with only two countries, Britain and Germany. Such detailed attention to these two major countries is of course wholly justified in itself, but one cannot gain a full understanding of unemployment, a crucial phenomenon in capitalist societies, without studying all national variants. From this perspective the extensive literature on interwar unemployment reveals considerable gaps, in that several Western European countries have received only scant attention (although it must be said that recently improvements have occurred in this regard). Within this group of relatively neglected countries Belgium holds a particularly unfortunate place. Only one study, recently published, has reached an in- 
ternational audience. ${ }^{1}$ And even in Belgium itself the topic was hardly studied until recently. ${ }^{2}$

This paper is intended to fill this gap to some extent. It approaches the issue from a specific angle. The economic determinants and developments and social consequences of unemployment in Belgium will remain outside its scope; instead, of the many facets thrown up by a complex phenomenon like unemployment it will examine the problem of the significance and the evolution of the institutional network woven around it. To describe the Belgian variant of this problem will mean more than adding an item to the catalogue of institutional arrangements. The development of the Belgian system of unemployment insurance provides an interesting addition to the extensive and complex dossier concerning the origins of the welfare state.

Without wishing to provide an overview, let alone an analysis, of the wide-ranging theoretical debate on the issue, I would like to refer to some of the more useful approaches. ${ }^{3}$ Complex institutional arrangement such as social security provisions are not the outcome of an inexorable process within a "modernizing society", which "needs" such institutions and which creates them automatically and uniformly. Rather, a society is confronted with a complex range of changing problems which creates the space and conditions for various potential arrangements. The concrete form of these arrangements is determined by the ways in which the classes and the state, in a confrontational process and on the basis of fluctuating balances of power and internal options, will support this or that arrangement. How then, did the balance of power between the social forces determine the development of unemployment insurance? What were the attitudes of industrialists, the labour movement and other social groups towards this aspect of social security? What role did the state play?

The theoretical premises and consequences of these problems cannot be explored here, nor can a contribution be made to international comparison by projecting the Belgian example onto the known outline of developments in other countries. We wish merely to provide a general sketch of a national variant, a sketch which other researchers may integrate into a broader context.

${ }^{1}$ See M. Goossens, S. Peeters and G. Pepermans, "Interwar Unemployment in Belgium", in B. Eichengreen and T. J. Hatton (eds), Interwar Unemployment in International Perspective (Dordrecht, 1988), pp. 289-324.

${ }^{2}$ More details can be found in G. Vanthemsche, De werkloosheid in België tijdens de jaren 1930 (Antwerpen, 1989).

${ }^{3}$ Of the vast literature on the subject, suffice it to refer to two recent and excellent surveys, which take different views: J. Alber, Vom Armenhaus zum Wohlfahrtsstaat (Frankfurt, 1982), pp. 73-118, and G. Therborn, "Neo-Marxist, Pluralist, Corporatist, Statist Theories and the Welfare State", in A. Kazancigil (ed.), The State in Global Perspective (Paris, 1986), pp. 204-231. 
The Ghent system of unemployment insurance before the First World War and during the $1920 \mathrm{~s}$

The neglect in contemporary historiography of the study of the Belgian variant of unemployment insurance is least justified with regard to its origins. As is well known, there emerged in Belgium, specifically in the Flemish industrial town of Ghent, a form of unemployment insurance which would exercise a powerful influence in the early development of this social insurance in Western Europe. The so-called "Ghent system" of unemployment insurance arose in the early years of the twentieth century and was one of the first effective forms of public intervention in this field. ${ }^{4}$ It was emulated throughout Western Europe, with varying success. Already before the First World War it had been introduced (albeit sometimes in slightly altered form) in many countries at either national, regional or municipal level, in particular in France, the Netherlands, Switzerland, Germany, Austria-Hungary, Norway, Denmark and Italy. ${ }^{5}$ The spread of

+ At the end of the nineteenth century similar types of public intervention also occurred in Switzerland (in Bern and Sankt Gallen, for instance), but these were far less successful than the Belgian systems. Important studies on the development of unemployment insurance in general include J. Garraty, Unemployment in History (New York. 1979). 2nd ed., pp. 129ff.; J. Alber, op. cit., and its English version, J. Alber, "Government Responses to the Challenge of Unemployment: The Development of Unemployment Insurance in Western Europe". in P. Flora and A. J. Heidenheimer (eds). The Development of Welfare States in Europe and America (New Brunswick and London. 1981). pp. 151-183, and A. Sinfield, "Unemployment", in P. Köhler and H. Zacher (eds), Beiträge zu Geschichte und aktueller Situation der Sozialversicherung (Berlin, 1983). pp. $415-471$.

5 The general studies mentioned in note 4 of course mention the Ghent system. So does G. A. Ritter in Social Welfare in Germany and Britain: Origins and Development (Leamington Spa, 1986), pp. 102 and 163. Some individual country studies also refer in passing to the application of the Ghent system within their national frontiers: e.g. $\mathrm{H}$. Henning, "Arbeitslosenversicherung vor 1914: das Ghenter System und seine Übernahme in Deutschland", in H. Kellenbenz (ed.), Wirtschaftspolitik und Arbeitsmarkt (München, 1974), pp. 271-287; F. Niess, Geschichte der Arbeitslosigkeit (Köln, 1979), pp. 168-177; A. Faust, Arbeitsmarktpolitik im Deutschen Kaiserreich (Wiesbaden, 1986). pp. 142-147; L. A. Heilman, "Industrial Unemployment in Germany 1873-1913" , in Archiv für Sozialgeschichte (1987), pp. 45f.; H. Hofmeister, "Landesbericht Österreich", in P. Köhler and H. Zacher (eds), Ein Jahrhundert Sozialversicherung (Berlin. 1981), pp. 633f.; P. de Rooij, Werklozenzorg en werkloosheidsbestrijding 1917-1940: Landelijk en Amsterdams beleid (Amsterdam, 1979), pp. 17-22, which deals with the Netherlands; H. Heclo, Modern Social Politics in Britain and Sweden (New Haven. 1974), pp. 70-78 and pp. 92-105; N. Unga, Socialdemokratin och arbetslöshetsfrågan 1912-1934 (Stockholm, 1976), pp. 25 and 98, which deals with Sweden, and A. L. Seip, "Motive Forces Behind the New Social Policy After 1870: Norway on the European Scene", Scandinavian Journal of History, 9 (1984), p. 340. (I did not have access to the vast historical literature on the development of social policy in the Scandinavian languages, e.g. the books by A. L. Seip, S. Kuhnle and P. Edebalk.) The Ghent system has even been discussed in the United States, e.g. by D. Nelson, Unemployment Insurance: 
this form of public intervention throughout Europe has yet to be comprehensively analyzed. It would make an interesting object of study, for the confrontation of a single coherent project with various national realities characterized by divergent economic, social and regional structures, specific internal social relations of power and different political and ideological traditions would throw an interesting light on the dynamics of the emerging welfare state. One of the key elements of the Ghent system was the large, almost exclusive, role allocated to the trade unions. This aspect also dominated the various national debates on the merits of the system. It may be examined in more detail with the help of a short description of the operation of the system in Belgium itself. ${ }^{6}$

Ghent, a large Flemish industrial city, had a considerable tradition of trade-union organization. By 1897 no less than 41 per cent of manual workers in the city (casual workers excluded) were members of a trade union. By the end of the nineteenth century most unions had set up funds insuring their members against unemployment in return for small regular contributions. These spontaneous union initiatives had a precarious existence, however, largely because of the funds' limited financial strength. In time the unions turned to the Ghent city council with requests for additional financial support. Although the country's three main political currents catholic, socialist and liberal - were represented in almost equal strength on the council, in 1900 it approved near unanimously a system of public intervention on unemployment conceived by the liberal lawyer and social

The American Experience 1915-1935 (Madison, WI, 1969), pp. 6-11. It should be noted that the 1911 National Insurance Act in Britain actually incorporated a variation of the Ghent system in a wider compulsory state scheme, changing consequently the impact the system was going to have e.g. in Belgium. The "orthodox" Ghent system had some influential advocates in the British labour movement, most notably the Webbs: see B. B. Gilbert, The Evolution of National Insurance in Great Britain: The Origins of the Welfare State (London, 1966), pp. 265-270; J. Harris, Unemployment and Politics: A Study in English Social Policy 1886-1914 (Oxford, 1984), 2nd ed., pp. 302-304, and K. D. Brown, Labour and Unemployment 1900-1914 (Newton Abbot, 1971), pp. 119-120. I was not able to consult the study by $\mathrm{C}$. Topalov, Aux origines de l'assurance-chômage: l'Etat et les secours de chomage syndicaux en France, en Grande-Bretagne et aux EtatsUnis (Paris, 1985). A chronology of the spread of the Ghent system is provided in Ville de Gand: Fonds intercommunal de chomage, reports from 1901 to 1911 (Gand, 1903-1912), mainly the reports for 1906-1908 and 1909-1911, and Les oeuvres de la Ville de Gand contre le chômage [. . J Ephémérides: Principaux événements intéressant ces oeuvres: Publié à l'occasion de l'Exposition Universelle de Gand 1913 (Ledeberg, 1913). A useful survey of the application of the Ghent system on the eve of the First World War in Europe is provided in Bulletin trimestriel de l'Association Internationale pour la Lutte contre le Chômage (January-February 1914), which contains national reports on the different systems of unemployment insurance.

${ }^{6}$ Further detail is provided in G. Vanthemsche, "De oorsprong van de werkloosheidsverzekering in België: vakbondskassen en gemeentelijke fondsen", Tijdschrift voor Sociale Geschiedenis, 11 (1985), pp. 130-164. 
researcher Louis Varlez. Under this system the city authorities paid unemployed members of a union fund a supplement (of between 50 and 100 per cent) to the allowance provided by the fund over a fifty-day period.

It is important to note the merely instrumental role of the unions in this system. Because the unions happened to be best placed to react to this social evil and to stimulate working people's sense of foresight, the authorities used them to counter the socially destructive and destabilizing impact of unemployment. It was definitely not their intention to strengthen the trade-union movement as such.

In this regard the Ghent system differed from another form of public intervention on unemployment, the so-called "Liège system", which had been set up also in Belgium three years earlier, in 1897, but was far less successful and thus far less well known. Devised by a socialist member of the executive of Liège province, this system was explicitly designed to provide support for unions involved in unemployment insurance. Under it the provincial authorities granted a subsidy directly to the union fund, while under the Ghent system the subsidy merely passed via the union to the individual unemployed worker. Moreover, the Liège subsidy was calculated on the basis of disbursed benefits and collected contributions, so that large unions little troubled by unemployment could still accumulate large sums of public money; the Ghent subsidy was paid out only in cases of actual unemployment. Two other aspects of the Ghent system illustrated the incidental, instrumental role of the unions. For one, the union funds had to advance the total allowance, both its own benefit and the municipal supplement, and they were only reimbursed by the municipality after supplying receipts. Supporters of the Ghent system argued that this arrangement encouraged the unions to use both their own and the city's money with prudence, for instance by checking on the unemployed themselves and guarding against fraud. It also encouraged workers who were not members of a union to plan ahead and to protect themselves against the possibility of losing their jobs. They could register with the city council as an "individual unemployment saver"; should they need to draw money from this account in case of unemployment, the municipality would pay a supplement equivalent to that paid out to union members. In practice, however, non-union-linked provision always remained marginal. Very quickly the trade unions became the only basis on which this form of public intervention relied.

The Ghent system of unemployment insurance in fact brought the labour movement considerable advantages. The frontline organizations, the unemployment funds, remained in the hands of the unions and were given a strong boost by the financial support from the public authorities: this stimulated recruitment and stabilized membership levels. The close interaction between public intervention and the labour movement formed the 
crux of the Ghent system and its most controversial aspect. Critics pointed out that it denied a safety net to a large section of the working class: the unskilled workers, and more generally those who did not belong to the class "elite", were traditionally not unionized and were therefore not eligible for support from the Ghent system. William Beveridge considered this a key argument for rejecting the Ghent system as the blueprint for unemployment insurance in Britain. ${ }^{7}$ In addition to the "efficiency argument" referred to earlier, the question of preferential treatment for union members - in other words the strengthening of the labour movement's appeal explicitly or implicitly informed the political debates on the Ghent system in the different countries. ${ }^{8}$ Moreover, it was not only the opposition of conservatives and employers that affected the fortunes of the Ghent system. The strategic option consciously or unconsciously taken by the labour movement itself with regard to its role in the organization of the social life of the people also was an important element in the debate. ${ }^{9}$ In fact these two factors, conservative opposition and the labour movement's strategic choice, would strongly influence the subsequent development of the Belgian system of unemployment insurance. We will return to this in more detail later.

As already mentioned, it is not our intention to trace the interplay of these two factors (and the possible impact of any others) in other countries in order to sketch the progress of the specific "Ghent" form of social insurance. Suffice it to say here that in the end the Ghent system did not prevail itself in the major European countries in the interwar period. Britain (even before the First World War, from 1911 onwards), Austria, Italy and Germany moved towards state insurance, the model which eventually became the most widespread in Western Europe. France developed only a rudimentary and incomplete form of unemployment insurance. Only

7 See J. Harris, William Beveridge: A Biography (Oxford, 1977), p. 138.

${ }^{8}$ See e.g. on this point as well as the following one: G. A. Ritter, Social Welfare, pp. 80f., pp. 99-103, 163, 172; H. Henning, "Arbeitslosenversicherung", pp. 281-283; J. Harris, Unemployment, pp. 304 and 330; N. Unga, Socialdemokratin, p. 226, and D. Wilson, The Welfare State in Sweden (London, 1979), p. 70.

9 The methods and motives behind the practice of "social administration" as performed by trade unions in Great Britain and Germany respectively after and before the First World War are analyzed in W. Krieger, "Das gewerkschaftliche Unterstützungswesen in Grossbritannien in den zwanziger Jahren" and K. Schönhoven "Selbsthilfe als Form von Solidarität: Das gewerkschaftliche Unterstützungswesen im Deutschen Kaiserreich bis 1914", both in Archiv für Sozialgeschichte (1980), pp. 119-146 and pp. 147-193, respectively. The Belgian variant of this practice and its consequences will be analyzed below. Louis Varlez, the inventor and promotor of the Ghent system, noted bitterly that the French labour movement was not interested in performing social protection functions, particularly unemployment insurance, thereby hindering the development of the Ghent system in France (see e.g. Ville de Gand: Fonds, reports for 1906-1908 and 1909-1911, pp. $66 f$. and pp. $60 f$., respectively). 
some of the smaller European countries - precisely those which have been neglected in the international historical literature - applied the Ghent system, adapted in one way or another, on a national scale and always on a voluntary basis: Norway and Denmark did so early, in 1906 and 1907 respectively; the Netherlands in 1914 and 1917; Belgium, ironically the country where the system had originated, followed only later, in 1920-1921; and Sweden adopted a similar arrangement after nearly thirty years of debate in $1934 .{ }^{10}$ It is not possible or intended here to discuss the structure and scope of each of these systems, some of which (in particular those in the Scandinavian countries) remain in place until this day. ${ }^{11}$ But at least the Belgian variant illuminates a few key aspects of unemployment insurance in general and raises a number of questions on crucial problems, including the opportunities and limitations of such a support system in a capitalist society, the attitude of employers and the labour movement, and the role of private and public intervention in the organization of the system.

The system introduced in Ghent in 1901 was very successful in Belgium. By 1913 there existed 29 municipal and intermunicipal unemployment funds (werkloosheidsfondsen). Although they covered only 101 of the

${ }^{10}$ Unemployment insurance along the lines of the Ghent system was also introduced in Switzerland, but its very complex organization (due largely to the existence of different systems at the cantonal and municipal levels) diverged from the pattern in the other "Ghent" countries in that union unemployment funds did not have a near-monopoly in the field. In 1930 around 40 per cent of insured workers were covered by public funds and joint employers/employees funds: see T. G. Spates and G. S. Rabinovitch, Unemployment Insurance in Switzerland. The Ghent System Nationalized with Compulsory Features (New York, 1931), and H. Treyer, L'assurance contre le chômage en Suisse (Paris, 1933). In France one element of the Ghent system, the subsidizing of private unemployment funds by the public authorities, survived throughout the interwar period. But union funds were less important than the system of direct public allowance set up through separate official unemployment funds which put the union funds at a disadvantage: see R. Salais, N. Baverez and B. Reynaud, L'invention du chômage: Histoire et transformations d'une catégorie en France des années 1890 aux années 1980 (Paris, 1986), pp. 128-129, and R. Salais, "Why was Unemployment so Low in France", in B. Eichengreen and T. J. Hatton (eds), Interwar Unemployment, pp. 255-258. Details of this (also rather complicated) system can be found in some obscure and old thèses de droit dating from the interwar period, in J. Malivoire de Camas, La France et le chômage: Étude de législation (Paris, 1933), and G. Héreil, Le chômage en France: Étude de législation sociale (Paris, 1932), and in the better-known work of $G$. Letellier et al., Enquête sur le chômage en France de 1930 à 1936 (Paris, 1938), vol. I. A comprehensive survey of the different systems of unemployment insurance in existence after the First World War is provided in various publications of the International Labour Office (ILO), e.g. Assurance-chomage et diverses formes d'assistance aux chômeurs (Genève, 1933).

${ }^{11}$ Concerning Denmark and Sweden, see e.g. L. N. Johansen, "Denmark" and S. Ohlson, "Sweden", in P. Flora (ed.), Growth to Limits: The Western European Welfare State Since World War II (Berlin and New York, 1986), vol. 1, pp. 34 and 298. Norway introduced compulsory unemployment insurance in 1938. See also J. Alber, Vom Armenhaus, p. 169. 
country's 2,629 municipalities, these accounted for 32 per cent of the total population. The municipal unemployment funds were the vehicles for public intervention in unemployment insurance. By 1910 all cities with a population over 35,000 possessed such institutions. Most of them were organized on the Ghent model; only a few applied the Liège system. The number of insured also grew steadily. In 1909 around 310 union unemployment funds (werkloosheidskassen) were affiliated to a municipal unemployment fund, covering 58,413 insured workers. By 1913 this number had increased to 634 funds with 126,278 insured, equivalent to around 10 per cent of the country's manual industrial labour force. ${ }^{12}$ At the same time unemployment insurance within the trade-union movement also gained in popularity. In 1900 only 25 of the 185 socialist trade unions operated an unemployment fund; by 1902 this had increased to 107 out of 200 . On the eve of the First World War around half of Belgium's union members were insured against unemployment. ${ }^{13}$ This raises, incidentally, an issue which complicates the analysis of the emergence and the impact of the Ghent system: it could not develop without some prior growth of the trade-union movement, which was the pin on which it hinged. But once introduced the system stimulated the growth of the trade-union movement, although it is difficult to isolate this factor from other causes of union growth. We shall return to this below.

Despite the success of this system of unemployment insurance at the grassroots level, some twenty years passed between its introduction in Ghent and its general application at national level through central-government intervention. ${ }^{14}$ This delay can be attributed to the relatively undemocratic nature of the Belgian political system prior to 1914 , with a form of plural voting keeping a conservative catholic government in power for decades. ${ }^{15}$ Before the First World War the trade unions had only very

12 The statistical material on unemployment funds and insured workers is not quite complete. There was no overall survey of the number of insured workers before 1909 . The 1909 figures are incomplete because they do not include existing union funds which had not yet affiliated to a municipal unemployment fund. The 1913 figures include the union funds and insured workers who were not affiliated to a municipal fund, but only if the union funds were "recognized" (usually catholic); they do not include the socialist union funds and their members not affiliated to a municipal fund.

${ }_{13}$ In 1900 there were about 30,000 socialist and 10,000 catholic trade-union members. According to the 1910 national census, the number of manual industrial workers totaled $1,185,000$. To these figures must be added the membership of a number of liberal and "neutral" trade unions (about 25,000 on the eve of the First World War). The significance of the existence of competing currents in the Belgian working class is analyzed in C. Strikwerda, "The Divided Class: Catholics and Socialists in Belgium 1880-1914", Comparative Studies in Society and History (1988), pp. 333-359.

${ }_{14}$ The central government had in fact given (very small) subsidies to unemployment funds since 1907, but it did not intervene directly in the payment of unemployment benefits. Most of the country nine provinces granted similar subsidies. 
limited freedom of action and had practically no influence on decision making at the national level. Under these circumstances the right's suspicions of unemployment insurance went unchallenged. The conservatives and the employers mistrusted it on two counts. Firstly, unemployment insurance went to the heart of the capitalist system, the labour market, and they had a basic aversion to devising an income mechanism for able workers outside and independent of the wage market. Unemployment benefit undermined the motivation to work, left few or no means of controlling whether people were really out of work, and impeded the essential flexibility of wage levels at times of crisis, they argued. In the course of the nineteenth century employers and the bourgeoisie had made some efforts to improve the social conditions of the working class by setting up funds against illness and old age, either directly linked to the factory or more generally based. But they had not made any attempt to compensate workers for the loss of income due to lack of work: by way of consequence, only the trade unions were active in this field. This situation was also at the root of the right's other reason for mistrusting unemployment insurance. The unions were "settling" new, unchartered territory, a phenomenon supported and strengthened within the Ghent system by the specific actions of local authorities. This added to their appeal and translated itself into increased membership. Unorganized workers who would find themselves without any means of support in case of unemployment (apart from public relief) had a strong incentive to join a union. Not enamoured of this situation, the conservatives and the employers also suspected that public money would not only benefit the unemployed but would also flow into strike funds. As far as they were concerned, public intervention by the state was out of the question, and hence also employers' contributions to any system, since these would not only increase production costs but also, and above all, strengthen the class enemy.

This rejection was removed by the First World War, when Belgium acquired for the first time a national unemployment system. This was important above all because it prepared people for the subsequent and permanent introduction of unemployment insurance in the postwar period, even though this system would differ considerably from the temporary wartime arrangement, which we will not discuss here. ${ }^{16}$ The war was also

15 Within this alliance, the christian democrats' influence grew in the years before the First World War. See E. Witte and J. Craeybeckx, Politieke geschiedenis van België sinds 1830 (Antwerp, 1981), ch. 3.

${ }^{16}$ Further details are provided in $\mathrm{E}$. Mahaim, Le secours de chômage en Belgique pendant l'occupation allemande (Paris, 1926). Although most of Belgium was occupied, there existed a private relief committee, the National Aid and Food Committee (Comité National de Secours et d'Alimentation), which supplied the population with the necessary foodstuffs with the approval of the Belgian government-in-exile and the permission of 
important because it created a new social and political balance of power, which in turn gave an important twist to the issue of unemployment insurance. To form a united front first to repel the German invaders and after liberation to overcome the difficult period of reconstruction, the three main political currents in Belgium, the catholics (themselves divided into a progressive and a conservative wing), the socialists and the liberals, had sought a rapprochement within the framework of governments of national unity. The new political arrangement, together with the fear of possible revolutionary uprisings in 1918-1919, led to several important measures: the introduction of an electoral system based on one-man-one-vote, which strengthened the position of the socialists in the political sphere ${ }^{.7}$ legalization of all trade-union activity and abolition of restrictions on the right to strike; and the introduction of various social measures, including the eighthour working day. The balance of power within society had also shifted fundamentally as a result of the explosion of trade-union membership: whereas before the war 230,000 wage earners had joined a union, by 1920 no less than 875,000 had done so. In addition, a system of direct bargaining between employers' and workers' organizations was beginning to take shape in various industrial branches.

Within this very dynamic context important decisions were also taken with regard to unemployment insurance. In 1918 the socialist leader Joseph Wauters was appointed minister of industry and labour. He introduced, in close association with the socialist Trade Union Commission (Commission Syndicale), a national system of voluntary unemployment insurance wholly based on the existing union unemployment funds. This system was in fact a combination of the Liège and the Ghent systems, and operated as follows. On the Liège model, the national government paid directly to the union unemployment funds a subsidy calculated as a percentage of the total contributions paid in (originally 50 per cent, later 66 per cent). On the Ghent model, the government intervened in several ways in the payment of benefit to the unemployed. The whole system continued to turn on the autonomous unemployment funds set up by the unions. For sixty days, the "statutory period", a union fund paid from its own resources a "statutory allowance" (statutaire vergoeding) to its unemployed members on the basis of the "insurance contract" concluded between the fund and its members. In addition the state paid a "family allowance" (familiale vergoeding), the level of which was dependent on the status of the unemployed person (a single people received no allowance, for example). The state would also

German occupying authorities and with the aid of the US Commission for Relief in Belgium led by Herbert Hoover. The special unemployment relief system of the Comité National entailed a significant reduction of trade-union influence in this field.

${ }^{17}$ In the first general election after the war 73 catholics, 70 socialists and 34 liberals were elected to the 186-member Chamber of Deputies, the lower house of parliament. 
pay the statutory allowance if a union could not fulfil its financial obligations or ran out of money, as might happen during a period of recession and increased unemployment. And finally the state also paid the allowance if the insured unemployed worker remained out of work beyond the sixty days of the statutory period. ${ }^{18}$ By 1931-1932 this "post-statutory allowance" (post-statutaire vergoeding) became effectively open-ended, and from that time an insured unemployed worker in Belgium could enjoy a substitute income for many years without interruption. But to qualify for the post-statutory allowance the unemployed had to be "in need", that is, his or her income and that of the family had to be below a certain level. A new government institution, the National Crisis Fund (Fonds National de Crise), was set up in 1920 to manage the state's new benefit system.

Over and above the various kinds of benefits provided by the union unemployment fund and the state the unemployed continued to be entitled to a range of direct subsidies from the municipalities and the provinces. There was little uniformity in the financial support provided by the local and regional authorities: by no means all authorities provided it and those that did had total discretion over the modalities of the supplement.

During this period of rapid and fundamental changes in Belgian society, with the labour movement on the offensive, the unions had succeeded, by means of an effective intervention on the political stage, in making their services for the unemployed increasingly attractive. Only union fund members were entitled to claim the various state benefits for the unemployed, and the extent and duration of state support meant that joining a fund was far more attractive than it could ever have been if the funds had had to rely on their own financial resources. Because the unions were the first and later the only organizations to offer this service, working people perceived a strong psychological link between the union and unemployment insurance throughout the 1920s and 1930s. Those who wanted to protect themselves from the financial consequences of lack of work automatically went to the union for support. Once the national government had become involved in 1920-1921 this decision was even more worthwhile than it had been before. The unions thus gained and maintained a near-monopoly in this field, although other, non-union-affiliated unemployment funds also emerged especially after the First World War: on the one hand public-sector insurance funds set up by several cities and municipalities and on the other employers' unemployment funds (to which we will return below). In 1930 the union unemployment funds accounted for 77 per cent of the total number of unemployment funds and for 97 per cent of all insured workers. ${ }^{19}$

${ }^{18}$ A good survey in English is provided in C. Kiehel, Unemployment Insurance in Belgium (New York, 1932).

${ }^{19}$ See ibid., pp. $148 \mathrm{f}$. 
Moreover, the unions were in total control of these insurance funds: their officials administered them; they determined the level of benefits; ${ }^{20}$ they were primarily responsible for checking up on claimants; and the state benefits (including the post-statutory allowance) were paid at the union cash desk, probably without the beneficiary always having a clear idea as to the source of the payments.

This situation reflected one of the Belgian labour movement's main aims, an aim never clearly spelt out doctrinally but permeating its activities rather diffusely. The labour movement wanted to expand its direct presence in the social sphere and wanted to play a major role in the management of the daily lives of working people. It achieved this through consumer cooperatives, for instance, which supported the activities of workers as economic agents, especially as consumers and savers. The numerous cultural associations did the same for intellectual life and leisure. The sickness funds, another important branch of the Belgian labour movement, provided a measure of social protection for ill or old workers and their wives and children. The aim, then, was for the institutions of the labour movement to be the first, and if possible the only, institutions with which workers would come into contact in their many-faceted social activities. The state should merely play a supportive, coordinating role in the background and supply the essential financial support (especially for the welfare facilities). The union unemployment funds in fact were only one, albeit a very important, component of a much broader strategy by the labour movement to become deeply rooted in the social fabric. But the funds were particularly important because they allowed the labour movement to strengthen its position at the heart of the capitalist mechanism, the labour market. It was able thus to mitigate some of the destructive effects of excessive competition among workers. In addition to this crucial but rather abstract aspect - incidentally, rarely spelt out ${ }^{21}$ - there was a second aspect which gave the union unemployment funds considerable importance. For through them the union movement, the backbone of the working class, gained considerable support. The steep rise in union membership after the First World War referred to above doubtless owed much to the existence of the state-supported unemployment funds. How much is difficult to say, since it is not easy to

${ }^{20}$ In theory, the total benefit granted to unemployed workers - the sum of the allowances of union unemployment fund, municipality and province and the state-could not exceed a maximum of $2 / 3$ or $3 / 4$ of their salaries. According to employers and conservatives this particular rule was consistently broken.

${ }^{21}$ See e.g. L. Delsinne, Le mouvement syndical en Belgique (Brussels, 1936), p. 245, and Mouvement Syndical Belge, 15 January 1921, p. 9 and 20 January 1931, p. 3. The interesting debates within the German trade-union movement before 1914 concerning the significance of the existence of a network of relief funds (particularly of unemployment funds) organized by the labour movement are analyzed by K. Schönhoven, "Selbsthilfe", pp. $168 \mathrm{ff}$. 
separate this specific factor from other causal factors such as greater working-class militancy during this period. The link between growing union membership and unemployment insurance is much more clearly evident during the subsequent period, the crisis of the 1930s, when unemployment soared. ${ }^{22}$

\section{The impact of unemployment insurance during the crisis of the 1930 s}

The number of union members in Belgium increased markedly from around 610,000 to 907,000 in the short period between 1929 and 1938 . There can be no doubt that this increase is explained by the flight of working people to the unemployment funds. Many statements by union officials attest to this. More detailed analysis of the modalities and rhythms of growth of union membership also points in this direction. ${ }^{23}$ On the eve of the economic crisis around a third of the total number of manual and non-manual workers in commerce and industry (around 1,850,000 in 1930) were affiliated to a trade union. On the eve of the Second World War this share had increased to around a half. The proportion of workers insured against unemployment in relation to this total is almost identical, since nearly all union members were ensured against unemployment and vice versa (with the exception of the public-sector unions, which did not need to operate unemployment funds). It is noteworthy that the phenomenon of uninterrupted growth of union membership during the depression occurred precisely in those countries which operated a more or less comparable Ghent system of unemployment insurance (Sweden, Denmark, Norway and the Netherlands), while unions in other countries with different unemployment-benefit systems had to cope with a loss in membership, at least in the initial and most devastating phase of the economic crisis. It is not clear to me whether a causal link can be established for the first group of countries, such as Belgium, between the specific organization of unemploy-

${ }^{22}$ It is impossible to analyze here the problem of unemployment in Belgium. Suffice it to say that in 1932,1933 and 1934 about 17 to 20 per cent of all insured workers were wholly unemployed (with a peak of 23 per cent in January 1935) and about 15 per cent were partially unemployed. Monthly figures are included in the official Revue du Travail, 1930-1939.

${ }^{23}$ See G. Vanthemsche, De werkloosheid, pp. 53-55. The catholic unions grew much more than the socialist ones. Catholic membership represented respectively 181,000 and 325,000 of the totals given above. Nor should one ignore the existence of some smaller unions, mainly the liberal unions (with about 14,000 members in 1929 and about 75,000 in 1939). A recent and detailed study on the history of the Belgian trade-union movement after 1914 is still lacking, but see J. Dhondt, "L'influence de la crise de 1929 sur les mouvements ouvriers en Belgique", in D. Fauvel-Rouif (ed.), Mouvements ouvriers et dépression économique de 1929 à 1939 (Assen, 1966), pp. 76-102. 
ment insurance and growth of union membership, and whether therefore the latter can indeed be attributed to a "refuge mechanism". ${ }^{24}$

Despite the quantitative growth, the crisis period was not a golden age for the Belgian trade-union movement, on the contrary, and this not only as a result of the factors which traditionally adversely affect workers' lives in times of economic crisis. Paradoxically, it was the system of unemployment insurance which caused enormous problems. The pivotal position which the unions had acquired in the management of the social lives of the people now brought some pernicious side effects. The influx of unemployed into the insurance funds overloaded the system. The additional administrative burden, which the unions were soon unable to bear, was made even heavier by the government constantly issuing new and sometimes confusing regulations. At times the union bureaucracy was thrown into total confusion..$^{25}$ Relations between the union apparatus and the grassroots became strained. Union officials regularly deplored the lack of union spirit among the new members, who had often only joined for the sake of the unemployment benefit. Confronted with a maze of government regulations and restrictive measures, the anger of the unemployed sometimes turned against their union's unemployment fund. Often the funds were not responsible for the difficult situation, but it was the institution with which the unemployed came into direct contact. ${ }^{26}$

Mass unemployment also presented the unions with a dramatic financial problem. Having to pay thousands of unemployed, the funds were often exhausted for long stretches (at which points the government took over their obligations). More importantly, however, the unions' other financial resources also came under tremendous strain. Keen inter-union rivalry, particularly between socialist and catholic ones, meant that each union

${ }^{24}$ Figures taken from G. S. Bain and R. Price, Profiles of Union Growth: A Comparative Statistical Portrait of Eight Countries (Oxford, 1980); G. Harmsen and B. Reinalda, Voor de bevrijding van de arbeid: Beknopte geschiedenis van de Nederlandse vakbeweging (Nijmegen, 1975), pp. 426-433; A. Prost, La CGT à l'époque du Front Populaire (Paris, 1964), p. 39; F. Hodne, The Norwegian Economy 1920-1980 (London, 1983), p. 25, and W. Galenson, Labour in Norway (New York, 1949), p. 175. The latter mentions the Ghent system as a "factor in preserving the integrity of the trade unions", a point reiterated by e.g. D. Wilson, The Welfare State in Sweden, p. 70. G. Therborn's analysis of the Swedish situation in "The Working Class and the Welfare State: A Historical-Analytical Overview and a Little Swedish Monograph", in P. Kettunen (ed.), Det nordiska i den nordiska arbetarrörelsen (Helsinki, 1986), pp. 24, 25, 50 and 66 suggests that this might not have been the case in that country. See also G. Therborn, "The Coming of Swedish Social Democracy", in E. Colotti (ed.), L'Internazionale Operaia e Socialista tra le due guerre (Milano, 1985), p. 577.

${ }_{25}$ See e.g. Le Métallurgiste (October 1932), p. 3; and Rapport au Xe Congrès de la Confédération des Syndicats Chrétiens 1932, p. 50.

${ }^{26}$ See e.g. Résumé des débats du Congrès syndical extraordinaire de la Commission Syndicale du 22 nov. 1936 (Brussels, 1936), p. 17. 
tried to attract as many uninsured workers as possible. Much effort was put into retaining affiliated workers and "poaching" workers from other unions. In this struggle for members the unions offered potential members a whole range of fringe benefits which had no statutory basis or were in some cases actually illegal. As a further strain on their finances, the union funds often advanced the supplements paid by the municipalities and the provinces, which had been unable to meet obligations as unemployment soared ${ }^{27}$ In this way the local authorities quickly accumulated considerable debts to the workers' organizations, which they could not repay in the short term. All these factors forced union leaders to call on their organization's other financial resources: to deal with the financial consequences of rising unemployment, strike funds, administrative funds and solidarity funds were exhausted. Especially in 1932 and 1933 many unions found themselves on the verge of bankruptcy.

So despite the increase in its membership during the depression the Belgian trade-union movement was confronted with particularly pressing problems. The particular organization of unemployment insurance, leading to administrative confusion, concentration of activity on tiresome management tasks and financial exhaustion, precipitated a real crisis which made many union members reconsider the aims and methods of their organization and the future of unemployment insurance. We will return to this later.

The unemployment crisis also elicited reactions from other groups and institutions. The employers and the conservative political parties had been very unhappy with the national unemployment legislation introduced in 1920-1921 at the instigation of the socialists and the unions. But the employers' attitude to unemployment insurance underwent a remarkable change over the years. While they had rejected it in principle during the nineteenth century and at the beginning of the twentieth, a new attitude subsequently began to take hold, especially after the First World War. They probably recognized that the introduction of such a system was inevitable, but they also became aware of the considerable social impact it could and did have. In short, not the principle of unemployment insurance as such but the concrete form which the system would take became the employers' main concern. Their anxiety increased as the insurance system took what they considered a dangerous turn. Some facts illustrate the new developments. Even before 1914 Louis Varlez, the originator of the Ghent system, acknowledged the criticisms directed at it, primarily preferential treatment of unions and their members and neglect of unorganized work-

${ }^{27}$ See M. Van Audenhove, "Histoire des finances communales 3e partie", in Bulletin trimestriel du Crédit Communal de Belgique (1983), suppl. 143. 
ers. To overcome these failings he proposed involving the employers in unemployment insurance through the creation of municipal "crisis funds" (krisisfondsen). In the same way that municipal unemployment funds supplemented the union funds' payments to the unemployed, so the crisis funds would supplement the payments of new employers' unemployment funds. The unions' and the employers' funds would operate in different spheres: the former would support those workers whose labour contract had been terminated, while the latter would compensate for the loss of income incurred by workers (whether or not insured with a union fund) who had been partly or temporarily laid off without termination of their contract. This proposal had been launched in Ghent, but not taken up, just before the war. But after the war it attracted some interest, especially from the employers in the textile industry. ${ }^{28}$

Nothing lasting came of this, but the employers provided other important proof of their new-found interest in unemployment insurance. Following liberation the government initiated a broad debate over the introduction of a totally new compulsory unemployment insurance. The employers at that point expressed their willingness to contribute financially to such an arrangement, with the proviso that they would also have control over the unemployment funds, so that they would no longer be exclusively in the hands of the unions. ${ }^{29}$ The employers, then, considered it essential to break the union monopoly on this type of insurance. The proposal foundered on union opposition, and the system introduced by the government in 19201921 - comprising government support for voluntary unemployment insurance schemes administered by the unions - gradually took on an air of permanence, although in principle it had only been a temporary arrangement. The employers, highly irritated by this state of affairs, tried to find a fitting response and decided to set up their own unemployment funds. Administered by the management of one or more large firms, they were supposed to counter the union monopoly on voluntary unemployment insurance. The figures quoted above show that the initiative ended in failure. By 1930 not even 3 per cent of workers were insured with an employers' fund.

On the whole, however, the employers' dissatisfaction with the organization of unemployment insurance in Belgium remained rather below the surface during the 1920 s. The country was experiencing an economic upturn, especially between 1926 and 1929, and in the summer of 1929, for instance, only 0.5 per cent of all insured workers were without work. ${ }^{30}$ The

${ }^{28}$ See the Archives of the International Labour Office, Geneva, U 3/4/7, correspondence Varlez, who had by now become a high-ranking ILO official.

${ }^{29}$ See La lutte contre le chômage, June 1921, pp. 18-47, and XXIe Congrès syndical tenu les 15-17 juillet 1922, transcript (Brussels, 1922), p. 41, on the socialist rejection of the proposals. 
unemployment-insurance system was not high on the political agenda. This changed very quickly in the $1930 \mathrm{~s}$, when the dramatic rise in unemployment made the issue a very sensitive one for the employers. They virtually ignored the problems experienced by the unions in operating the insurance system during the crisis and instead became obsessed by the rush of workers to join union unemployment funds and therefore also the unions. And all this was made possible to a large extent with financial support from the state! The employers also felt that consequently the unions had no incentive to act against scroungers. In fact they accused the unions of seeking to obtain state funds by illegitimate means in order to stimulate recruitment campaigns. ${ }^{31}$ They also opined that the labour movement increased its numerical strength through unemployment insurance and thereby acquired a dangerous position of power within society: it provided support for unemployed workers through the funds; and it controlled and managed these without any outside interference and could unilaterally set the levels of benefits. In short, through its hold on the unemployment-insurance system the labour movement could exercise a major influence over the labour market and thus disrupt the "natural operation" of the system..$^{32}$ The argument that unemployment insurance caused chronic unemployment, first put forward by J. Rueff, gained widespread and strong approval from Belgium's conservatives and employers. ${ }^{33}$

The specific organization of unemployment insurance in Belgium created an additional problem. As mentioned above, where the unions could exercise a degree of influence over local authorities (through the socialist and christian-democratic political organizations) municipalities and provinces provided, in a rather haphazard manner, supplements to the basic benefits paid out by the union unemployment funds and the state. The employers argued that these "partisan" unemployment subsidies exacerbated the basic problem of unemployment insurance. In some regions the

${ }^{30}$ See F. Baudhuin, Histoire économique de la Belgique 1914-1939(Brussels, 1946), vol. 1, pp. 175-218.

${ }^{31}$ See Bulletin du Comité Central Industrial( $(C C I), 1$ March 1933, p. 214 . A general summary of the employers' criticisms can be found in P. Goldschmidt and G. Velter, Le soutien des chômeurs en Belgique dans le cadre de l'assurance-chômage (Brussels, 1931), and L'évolution du régime belge du soutien des chômeurs (Brussels, 1934).

${ }^{32}$ See e.g. Revue Industrielle, 7 November 1932, p. 2, and Usine Belge, 16 January 1932, p. 135 .

${ }^{33}$ See J, Rueff, "L'assurance-chômage, cause du chômage permanent", in Revue d'Économie Politique, March-April 1931. A similar theory is still being put forward in scientific publications, for instance in the famous Benjamin and Kochin paper in Journal of Political Economy of June 1979, giving rise to much controversy over its very reductionist approach to what, as e.g. Glynn and Booth demonstrated, is a "multiple problem". On conservative reaction, see e.g. L. Vertongen, "Le chômage, causes et remèdes", in Le Flambeau, July 1932, p. 20, and "La loi de Rueff", in Revue Economique Internationale, December 1932, pp. 30f. 
supplements could be much higher than in others, and as a result the labour market was particularly segmented and in some areas not flexible enough because there was insufficient stimulus to look for work. The national government and the employers had no means of influencing this state of affairs. And the straw that broke the camel's back as far as the conservatives and the employers were concerned was the fact that the state (and the local authorities) had to allocate huge sums to paying unemployment benefits. ${ }^{34}$ This went diametrically against the right's macro-economic priority, namely the reduction of public spending. Deep expenditure cuts would, according to the reigning orthodoxy, make economic recovery possible and even guaranteed it. Yet government spending on social services, more specifically on unemployment benefit, remained constant or even rose during the 1930s. The unions, as key players in the benefit mechanism, were accused of doing nothing to staunch the outflow of funds, rather the opposite. Thus the labour movement's strong roots within society and above all its control of the pivotal institution of unemployment insurance became a major concern for the conservatives and the employers. Reversing this situation was a high priority.

Reactions to the challenges posed by unemployment insurance during the $1930 s$

For ten years unemployment and unemployment insurance took centre stage in the concerns of the country's various social forces and the government. The ensuing intense political debates produced a number of major policy changes which reflected the interests of the employers rather than the labour movement. From 1927 until March 1935 Belgium was ruled by conservative catholic-liberal coalition governments. Throughout this period the socialists languished in opposition. The conservative government willingly lent an ear to the mouthpiece of employers' interests, the national employers' federation, the Central Industrial Committee (CCI), which was particularly strongly represented in the traditional heavy industries (mining, metal, glass etc.). ${ }^{35}$ During the first half of the 1930 s the government launched an array of initiatives intended to root out the worst "excesses" of the unemployment benefit system. These included removing workers from unemployment insurance by tightening conditions for eligibility, reducing benefit payments and tightening conditions for eligibility for these

${ }^{34}$ In 1932 central-government expenditure on unemployment benefits amount to around 1 billion francs, out of a total budget of around 10 billion francs.

${ }^{35}$ The industrial firms belonging to the sectoral employers' associations affiliated to the CCI in 1939 employed around 850,000 out of a total of $1,150,000$ wage-earners in industry (Bulletin du CCI, 22 March 1939, p. 412). 
payments (in particular by circumscribing the "in need" criteria for the post-statutory allowance). Although we will not deal with these complex developments any further, one other important aspect should be stressed, namely the government's policy of centralization. The uncoordinated local initiatives, which in the eyes of the employers pushed benefits to excessively high levels in some areas and made the labour market disordered and inflexible, were abolished. From 1933 onwards the municipalities and provinces were no longer allowed to contribute to unemployment benefits. The municipal unemployment funds, which had previously played a major administrative role (also by exercising some control over the union unemployment funds) but which subsequently became, according to the conservatives, a tool of the unions and progressive politicians, were replaced by regional institutions directly linked to the central government. ${ }^{36}$

Despite these measures, the crux of unemployment insurance, the monopoly position of the unions, remained unchanged. The abolition of union unemployment funds would have precipitated a direct and dangerous power struggle with the trade-union movement, something which the employers and the conservatives would not countenance at this stage. The conservative government needed the parliamentary support of the christian democrats to remain in office, and the latter had made the retention of the funds a precondition for their continued support. ${ }^{37}$ But as the economic crisis worsened, the positions of the opponents of union involvement also hardened. "Whether one likes it or not, it will be imperative to grasp the nettle and put an impenetrable barrier between the system of unemployment insurance and the trade unions", as a major employers' organization in the metal industry remarked. ${ }^{38}$ Towards the end of 1934 and in the early months of 1935 government circles began seriously to discuss the possibility of abolishing the union unemployment funds and replacing them with a government-run scheme.

In the end the trial of strength between government and employers on the one hand and the trade unions on the other never took place. From March 1935 onwards the country's economic situation began to improve, partly due to a successful devaluation of the franc carried out by a new government of national unity (including socialist ministers) led by Paul van Zeeland. Unemployment fell sharply: whereas 23 per cent of all insured workers were unemployed in January 1935, the number had fallen to 11 per cent

\footnotetext{
${ }^{36}$ See G. Vanthemsche, "De rol van de gemeenten in het systeem van werkloosheidsverzekering tijdens de krisisjaren 1930 in België", in L'initiative publique des communes en Belgique 1795-1940: Actes du 12e colloque international du Crédit Communal à Spa, 47 septembre 1984 (Brussels, 1986), vol. 1, pp. 461-480.

${ }^{37}$ See e.g. CSC-Bulletin, August-October 1931, p. 202, and April 1932, p. 175.

${ }^{38}$ Archives Fabrimetal, "Rapport annuel du Bureau de l'Association Patronale des Constructeurs de Belgique", 1933, p. 9.
} 
by the summer of 1936 . The government also jettisoned the restrictive austerity policy of the first half of the 1930s, also a consequence of the stronger presence of representatives of the labour movement. Consequently the whole debate on unemployment insurance lost some of its edge.

Against this, however, the immediate pre-war years (1936-1940) were dominated by long and vigorous debates over the introduction of a scheme of compulsory unemployment insurance. These debates throw an interesting light on the origins of the system of social insurance introduced in Belgium in 1944 and which remains in force until this day. It would therefore be informative to deal with this problem in some detail.

As mentioned earlier, the replacement of voluntary unemployment insurance by a compulsory system had been discussed in Belgium some years earlier, immediately after the First World War. But during the 1920 s and the early 1930 s no one seriously pursued this reform. Both the employers and the workers' organizations feared that the outcome of such a change would be to their disadvantage. But the depression years created a new situation. The strains put on the unions as a result of mass unemployment gave greater currency to a view already aired in embryonic form within the union movement before the crisis. Some argued that the concentration of the unions' energies and financial resources on unemployment led to a neglect or even an abandonment of other tasks, the unions' real tasks, in particular the conduct of industrial disputes or strikes. Union officials cautioned against strike action because the union would not be able to withstand its effects financially. Would the labour movement therefore not be better off by ending its involvement in the administration of unemployment insurance and leave this to the state? This argument was put forward with increasing frequency within the socialist trade-union federation, the Trade Union Commission (Commission Syndicale), in particular by the national leadership and several regional and sectoral organizations from Wallonia, which wanted to put greater stress on the class struggle which in their view was being neglected in favour of purely bureaucratic work. ${ }^{39}$ Socialist union leaders used the opportunity offered by a spontaneous nationwide general strike in June $1936^{40}$ to obtain a pledge from the national-unity government to introduce compulsory unemployment insurance.

The government called on Henri Fuss, a Belgian specialist on unemployment insurance with socialist leanings and a senior official at the International Labour Office (ILO) in Geneva, to prepare this important reform.

${ }^{39}$ See e.g. Mouvement Syndical Belge, 20 February 1936, p. 35, and Centrale des Métallurgistes, meetings of the national committee of 18 May 1933 and 28 November 1935 , available on microfilm from the National Archives, Brussels.

${ }^{40}$ See C. Strikwerda, "The Belgian Working Class and the Crisis of the 1930s", in W. Maderthaner and H. Gruber (eds), Chance and Illusion: Labour in Retreat: Studies on the Social Crisis in Interwar Western Europe (Vienna and Zurich, 1988), pp. 279-304. 
Appointed as the royal commissioner for unemployment, Fuss was asked to study all aspects of the issue and prepare a report on the basis of which the government would present a bill to parliament. The fact that the submissions made to Fuss differed widely and that some were irreconcilable provides an indication of the controversial nature of the planned reform, which many regarded as "the most important reform ever submitted to the legislature". ${ }^{41}$ Few of the protagonists doubted that the eventual institutional shape of the new compulsory scheme of unemployment insurance would have far-reaching implications for the balance of power between the social forces.

The employers' standpoint was unequivocal. It was imperative that the new system break the hegemony of the unions in this sphere, that it be transferred from the private to the public sector ${ }^{42}$ Paradoxically, then, the employers, as well as the liberal and the conservative politicians, argued for an extension of state intervention, on the grounds that this would reduce the influence of the trade-union movement, in the social sphere. They also argued for a bipartite management of the new public institution, with representatives of both employers' organizations and trade unions jointly running the system. Through this neo-corporatist arrangement they thought they would be able to exercise control in an area previously closed to them.

The labour movement, on the other hand, was deeply divided. ${ }^{43}$ The majority was resolutely opposed to the introduction of a state insurance and intent on retaining control of the scheme in the hands of the unions. It was felt that state insurance would cause a dramatic collapse of membership, while the retention of union-based funds within a system of compulsory insurance would result in significant increases in membership. Apart from the survival of the union unemployment funds as such, the majority also insisted on the incorporation of various specific, apparently technical details. For instance, it wanted the union unemployment funds to organize the collection of contributions and the payment of benefits, on the grounds that both these administrative aspects had a strong bearing on the role and the presence of unions in society. ${ }^{44}$ Working people would thus be most directly

${ }^{41}$ Usine Belge, 10 December 1938, p. 65.

${ }^{42}$ See Bulletin du CCI, 30 December 1936, p. 1723; and 26 May 1937, pp. 650-666.

${ }_{43}$ See Congrès syndical extraordinaire consacré à l'étude du problème de l'assurancechômage obligatoire [...] le 22 nov. 1936 (Brussels, 1936); the $2 e$ and $3 e$ Congrès syndical extraordinaire [. . . 8 août 1937 and 29 mai 1938 (Brussels, 1937 and 1938, respectively) for the socialist views, and Verplichte verzekering tegen onvrijwillige werkloosheid, memorandum drafted by the executive of the ACV (Brussels, 1937) for the catholic views.

44 And not the system of deduction (précompte) under which employers deducted workers' contributions from their salaries and transmitted them directly (with their own contributions) to the state's central unemployment fund. 
involved in the scheme and they would be protected by their own organizations. The christian-democratic union federation, the General Christian Trade Union (ACV), argued particularly vehemently for the "maximalist" position and wanted to retain the prominent role of the unions as much as possible under the new compulsory system. Apart from wanting to strengthen the unions for its own sake, the ACV had another specific reason for taking this stand, namely its desire to consolidate the ideological and moral christian presence within Belgian society. Belgian society was, and still is, characterized by the so-called system of "pillarization" (verzuiling), in which every ideological current - catholic, socialist and, to a lesser extent, liberal - organized for its adherents a whole network of institutions and services covering all aspects of social life.$^{45}$ The catholic pillar was the most developed, and the preservation of the union unemployment funds, including the christian ones, was regarded as an important foundation for a strong trade-union movement, which was itself a key factor in the social and cultural presence of catholicism in Belgian society.

These positions did not have the support of the whole labour movement, however. As mentioned earlier, part of the socialist labour movement argued that by retreating from managing working people's social lives the unions would be able to operate much more efficiently and even become more militant. In this view the administration of unemployment insurance (as well as other social welfare schemes, such as health and disability insurance) by the state would in no way threaten the emancipation of the working class.

Although supported by only a minority of the labour movement in 1936 and 1937, Fuss opted in his report to the government for a toned-down state-run system of compulsory unemployment insurance.$^{46} \mathrm{He}$ had a strong affinity with the views of the leaders of the socialist trade-union federation, who leaned towards state insurance and were also attracted by the "technocratic" element of a simple, rationalized administrative apparatus without the dead weight of the union unemployment funds.

It is not possible within the scope of this paper to discuss in detail the fortunes of the Belgian project of compulsory unemployment insurance. ${ }^{47}$ Suffice it to say that Fuss' proposals did not carry the day. At first, under heavy pressure above all from the christian unions, the Chamber of Deputies (the lower house of parliament) in 1938 approved a bill which reaffirmed the role of the unions in the organization of unemployment insur-

45 An excellent introduction to the issue of pillarization, on which there exists a vast literature, can be found in a special issue of the Revue Belge d'Histoire Contemporaine, 1982, nr. 1.

${ }^{46} \mathrm{H}$. Fuss, L'Organisation de l'assurance obligatoire contre le chômage (Brussels, 1937), and L'organisation, second report (Brussels, 1937).

${ }^{47}$ For such detail, see G. Vanthemsche, De werkloosheid, ch. 4. 
ance. In fact it even strengthened the unions' position, because henceforth all working people would be required to join one of the existing unemployment funds. It was therefore to be expected that several hundred thousand workers would now join a trade union, and the introduction of a compulsory and national Ghent system indeed meant in practice compulsory affiliation to a trade union for all workers. Under these conditions and in view of the existing power relations within society it would be virtually impossible for other insurers (that is, the public-sector and employers' funds) to attract new members.

The looming compulsory union membership for all workers filled the conservatives and the employers with horror. They focused their efforts to scupper the project on the Senate, the upper house, which also needed to approve the bill before it could become law. "Let us be quite clear about this: the adoption of this bill by the Senate [. . .] would be disastrous for social peace and [. . . ] for the national economy." "I8 "In future one in every two adults in Belgium would be a member of a trade union, a situation without compare in any other country. Trade unionism would be strong enough to take over the government itself. And then, inevitably, one would witness the crushing of one social class [ $=$ the employers $]$ by another $[=$ the workers]." 49 The employers' organizations and the conservative politicians mobilized. By means of complex parliamentary manoeuvres they succeeded in blocking the bill in the Senate. The impasse remained until the Second World War, and compulsory unemployment insurance was never introduced in Belgium in the interwar period.

But the outbreak of war did not mark the end of the story. During and immediately after the German occupation a decisive breakthrough occurred which led to the introduction of a general and compulsory system of social security in Belgium in December 1944, barely a few months after liberation. The new system regulated unemployment insurance as well as health and disability insurance, which for decades had also been the subject of inconclusive debates. ${ }^{50}$ These developments cannot be discussed further here, for they would require a very specific analysis. But it should be noted that the new system of compulsory unemployment insurance had many statist elements. More specifically, it had a close resemblance to the model proposed by Fuss before the war, which, as we saw, had been rejected by a majority of the labour movement in favour of more union-oriented schemes. How could the Fuss model be adopted so easily and quickly a few years later? The answer lies in the devastating impact of the war. The nazi

${ }^{48}$ Bulletin officiel de la Chambre de Commerce de Bruxelles, 23 October 1938, pp. 709-711.

${ }^{49}$ Le Flambeau, 15 February 1939, p. 177.

${ }^{50}$ Two other aspects of general social security, old-age pensions and family allowances, were made compulsory in 1924 and 1930 respectively. 
occupation from 1940 to 1944 had crippled the trade unions. The wartime authorities had transferred their responsibilities in the administration of unemployment benefit to the local commissions of public welfare. Thus in practice independent union unemployment funds had ceased to exist by the end of the war. But more importantly, the measures of 1944 were the outcome of a compromise over the social future of the country worked out clandestinely by representatives of the employers' federation, the tradeunion federations and senior civil servants. These people, including Fuss himself, formed precisely that socio-economic and administrative elite which on the whole had been well disposed to the Fuss plan. Opposition to the scheme and support for the retention of the union unemployment funds was most forcefully articulated by second-rank representatives of the labour movement (above all from within the christian organizations), which had remained somewhat on the sidelines during the negotiations.

The unemployment-insurance system of 1944 , then, broke with the past not only because a compulsory scheme replaced the earlier voluntary one, but also because it contained no trace of the pre-war autonomous union funds. From now on unemployment insurance was administered by a public agency directed jointly by representatives of employers and workers. Probably at the insistence of the less statist-minded representatives of the workers' organizations in the clandestine negotiations, the unions were nevertheless allocated a specific role. Those insured who so wished could receive their unemployment benefit - now wholly "public"51 - via a special payment service run by the union of their choice. The others were paid by a specially designated state agency. This option retained for working people at least a minimal psychological and administrative link between union membership and unemployment benefit. ${ }^{52}$ Overall, however, the settlement of 1944 signaled, around half a century after its emergence, the final abandonment in Belgium of the Ghent system of unemployment insurance in favour of a state-run system which remains in force until today.

51 The disappearance of the autonomous union unemployment fund logically meant the end of separate allowances sourced from private insurance funds and from public authorities.

${ }_{52}$ As noted earlier, the perception of contributions was a controversial issue before the war, because it was supposed to have an impact on the relationship between the workers and the labour movement. The catholic trade unions were especially keen on retaining this administrative link between the insured workers and the unions. The 1944 system withdrew this prerogative from the unions: the "précompte" system in note 44 was then introduced not only for unemployment insurance but also for the other fields of social security. 


\section{Concluding remarks}

What general conclusions can be drawn from the evolution of unemployment insurance in Belgium? In some recent articles Göran Therborn developed an analysis of what he called the "working-class perspective of the welfare state", which requires, among other things, that "the executive power within social security has to be in the hands of the organizations of the working class, on the basis of autonomy". ${ }^{53}$ In Belgium this element came strongly to the fore. Specifically with regard to unemployment insurance it was developed further than in larger Western European countries like Britain, Germany and France. That is precisely why the Belgian variant of the "road to the welfare state" is of some interest.

As a result of various historical coincidences, ${ }^{54}$ the trade unions had become the pivot around which the system of protection against loss of work turned. The Belgian labour movement had succeeded in establishing a strong presence in the "unchartered territory" of unemployment insurance. Exploiting its strength both at national and local level it was able to use the state apparatus to consolidate this presence and to extend it. This heightened the profile and increased the use value of the labour movement for working people. In this way it also acquired a significant potential influence on the operation of the labour market. The far-reaching implications of this situation became apparent during the crisis of the 1930s, when the number of organized workers rose considerably because the unions functioned as "refuges" for the working class. The high degree of autonomy enjoyed by the union unemployment funds and the local authorities (on which the labour movement could often bring considerable pressure to bear) made it possible for them to influence wages, conditions of work and, crucially, the material position of the unemployed (by setting the terms of "availability for work" and the levels of benefit, for instance). Unemployment insurance thus became a mechanism for protecting the interests of the working class, a mechanism that did not a priori take account of what employers and conservatives considered the exigencies of the capitalist

${ }^{53}$ G. Therborn, "The Working Class and the Welfare State" and "Classes and States: Welfare State Developments 1881-1981", in Studies in Political Economy (1984), pp. 1-13 and pp. 21-24. His analysis is based primarily on the pre-1914 programmes of the labour organizations in some important Western European countries and of the Internationals.

${ }_{54}$ These included the relative strength of the Belgian labour movement at the end of the nineteenth and the beginning of the twentieth century: its strong tradition of pragmatism, gradualism and protection; the quite efficient links existing between trade unions and political organizations; the application, to their logical consequences, of the concepts of self-help and"subsidized liberty" advocated by bourgeois circles; the circumstances of the war, the turmoil caused by it and the subsequent installation of governments of national unity. 
economy. Moreover, the specific organization of unemployment insurance in Belgium became one of the most intractable variables in the arguments over public-expenditure cuts, which according to the prevalent orthodoxy in the 1930s constituted a crucial element of macro-economic recovery.

The labour movement eventually lost the hold it had acquired on an important aspect of social life. The focus of the organization of unemployment insurance shifted from the "private" sphere (the unions) to the "public" (the state). This change, the nationalization of the system, had a neutralizing effect on the potential flashpoints inherent in the earlier form of unemployment insurance. These have become less visible, judging from today's perspective, and this has lent the prominent role of the state in this sphere, as in many others, a degree of self-evidence which obscures the fact that the present form of organization was not preordained. State control was not the only possible and inevitable outcome of the historical process. That it came to state control was determined then, and must be explained now, by the struggle between various social forces. How can one explain from this perspective the shift of unemployment insurance in Belgium from the private to the public sphere?

The pressure exerted by employers and conservatives was of course very important. Attacks on the supposedly intolerable hegemony of the unions in the sphere of social security was a recurring theme in their arguments and actions. Quantitatively and qualitatively unemployment insurance linked working people more closely to organizations which employers at the time portrayed not so much as "social partners" but as "class enemies". It also posed a threat to the smooth running of the economic machine. To overcome this double evil the employers and conservatives advocated the nationalization of the system, which they thought would enable them to exercise greater control over the labour market and would deprive the unions of one of their trump cards. So in this concrete case the extension of state responsibility was certainly not the unilateral result of workers' demands, but rather the outcome of a complex social struggle.

But other pressures for nationalization can be traced back to the labour movement. Their onerous involvement in the management of the social life of the people brought the unions a range of problems, both financial and organizational, which in turn led to a neglect of other union activities. Particularly among socialists the view gained ground that the labour movement should no longer shoulder the tiresome protective functions which could be better discharged by the state. Some people argued for such a transfer because it would make the union apparatus more efficient and more rational; others, of a more radical bent, did so because it would stimulate the class struggle; and yet others were attracted by the "technocratic" view and the logic of a streamlined state apparatus. 
Did a consensus over nationalization develop between the employers and the conservatives on the one hand and the labour movement on the other? ${ }^{55}$ On the form of the option, perhaps, but certainly not on the substance. After all, the underlying aims of the various forces were wholly contradictory: for the employers state control meant repulsion of a successful offensive by labour, for the labour movement it meant development of stronger anti-capitalist dynamic. The "consensus" was also qualified by the fact that large sections of the Belgian labour movement - a majority before the war were opposed to relinquishing social-welfare functions on the grounds that such a move would considerably weaken the movement. ${ }^{56}$ Moreover, the internal debate over unemployment insurance constituted but one aspect of a much broader issue which was and is of fundamental importance to the labour movement, namely the definition of its tasks. How should the movement define its relationship with the bourgeois state? Should it fight a flexible and mobile offensive struggle with as little institutional "baggage" of its own as possible? Or should it, rather, build its own "strongholds" controlled in full by the working class and whose rules could be set independent of the capitalist logic (by developing cooperative production and consumer organization and financial, cultural and social-security institutions, for instance). The second option, it should be noted, did not automatically imply rejection of reliance on the state. As the Belgian example shows, state intervention could be used as a support for or an extension of autonomous workers' initiative without the specific priorities of this initiative becoming subordinate to the state or being pushing into the background.

However, the labour movement rarely developed or formulated a theory of "refuges", of protected autonomous spheres of activity independent of capitalist production and the bourgeois state, just as it did not theorize much about the nature and the role of the state itself. The practice of "refuges" consisted solely of a pragmatic and gradualist approach to social issues. Several factors put this practice under severe strain: the employers' counteroffensive, the divergent views within the labour movement, and the dramatic impact of war and economic crisis (which exposed above all the feebleness of its financial foundations). No adequate counterweight existed to balance the combined effect of all these factors and to give priority to the defence at all costs of patiently erected bastions. As a result many functions, especially the social-protection function, were transferred to the

${ }^{55}$ The "consensus" view is criticized e.g. in I. Gough, The Political Economy of the Welfare State (London, 1979), pp. 65f., and in P. Thane, The Foundations of the Welfare State (London, 1985), 3rd ed., p. 291.

${ }_{56}$ Those were the views of the catholic labour movement (for whom the religious motive was a supplementary reason for keeping the labour movement's initiative intact), of the mainly pragmatic Flemish socialists, and even of the small Belgian communist party. 
public sector. Throughout this process the postulate of the neutrality of the state apparatus was never questioned and the potential structural side effects and implications of state control were rarely thought through. A socialist union official in exile in London during the Second World War commented as follows on Beveridge's model of the welfare state: "This social-security model leads up to the comfortable integration into the capitalist system, while leaving the workers a secondary position within the nation, in which they are after all the majority. [. . . It is up to them to take a greater share in the organization of society and in its wealth. [. . .] The Beveridge plan [is] one of the many means used by our masters to channel our aspirations." ${ }^{57}$ Such evaluations of the effects of social security and of the bourgeois state in general were isolated, however: extending the role of the state seemed more than ever a logical and automatic purpose of the action of the labour movement.

${ }^{57}$ Quoted is Artus (of the public-sector trade unions), "Réunion du Comité du Centre Syndical Belge", 10 June 1943, in D. Smets and J. Rens, Historique du Centre Syndical Belge à Londres 1941-1944 (Brussels, 1976), pp. A II 41 and A II 45. 